\title{
Association of Godoy \& Godoy contention with mechanism with apparatus-assisted exercises in patients with arm lymphedema after breast cancer
}

\author{
This article was published in the following Dove Press journal: \\ International Journal of General Medicine \\ 9 May 2011 \\ Number of times this article has been viewed
}

\author{
Maria de Fátima Guerreiro \\ Godoy ${ }^{1,4}$ \\ Tania Dias Guimaraes ${ }^{2}$ \\ Antonio Hélio Oliani, \\ José Maria Pereira de \\ Godoy $^{4}$ \\ 'CAPES (Coordination of \\ Improvement of Higher Education \\ Personal), São José do Rio Preto, \\ Brazil; ${ }^{2}$ Godoy Clinic, São José do \\ Rio Preto, Brazil; ${ }^{3}$ Gynecology and \\ Obstetrics Department-FAMERP. \\ São José do Rio Preto, Brazil; \\ ${ }^{4}$ Cardiology and Cardiovascular \\ Surgery Department-FAMERP \\ São José do Rio Preto, Brazil
}

Aim: The aim of the current study was to evaluate the reduction in the volume of the upper limbs with lymphedema after exercises using the apparatus-assisted program associated with contention mechanism.

Patients and method: Twenty-eight female patients were selected and referred for evaluation and treatment of lymphedema after breast cancer therapy. The ages of the women ranged from 42 to 72 years with a mean age of 57 years. Inclusion criteria were treatment of cancer associated to a difference of at least $200 \mathrm{~mL}$ between the edematous and the contralateral limbs. Patients with active infections, skin lesions, and active disease were not included in the study. Four series of exercises using devices based on pedals, pulleys, a horizontal reflexion bar, and an elevation bar were selected. The participants were advised about the form of exercise: 15 minutes for each device, low intensity (less than 10 movements per minute), in the seated position, and the use of contention. Water displacement volumetry was performed before and after the 60-minute exercise session. The paired $t$-test was utilized with an alpha error of 5\% considered acceptable $(P$ value $<0.05)$.

Results: The mean difference between the volumetric measures before and after exercise was significant, with all the participants having reductions in the volume of the limbs using the four selected devices over time and at an intensity determined by this study.

Conclusion: Association of a Godoy and Godoy contention during apparatus-assisted exercise reduced the edema in patients with lymphedema of the upper limbs.

Keywords: lymphedema, exercises, devices, treatment

\section{Introduction}

Lymphedema is one complication of breast cancer treatment. The hypothesis of the authors is that these procedures damage the lymphatic system and make drainage of proteins and macromolecules from the cell interstice difficult. ${ }^{1}$

When lymphedema is established, the degree of dysfunction is great due to physical factors such as the reduction in joint mobility causing reductions in the amplitude of movements, weight of the limb, pain, and disability in performing day-to-day tasks. ${ }^{2}$ Apart from this, the psychological state of patients is affected from the moment of breaking the news to coping with the treatment and any possible sequels. Sequels of mastectomized patients require multidisciplinary care, ${ }^{3}$ both in the prevention and treatment. On the other hand, there is consensus in respect to treatment with an association of therapies being recommended ${ }^{4,5}$ including lymph drainage, ${ }^{6-10}$ lymphokinetic
Correspondence: Maria de Fátima Guerreiro Godoy Rua Floriano Peixoto, 2950, São José do Rio Preto-SP, Brazil I5020-0I0

Tel/Fax +55 I7 32326362

Email godoyjmp@riopreto.com.br 
exercises, ${ }^{11,12}$ stockings and bandages,${ }^{13-15}$ hygiene and day-to-day care, ${ }^{16}$ investigation of quality of life,,${ }^{17}$ nutritional support, ${ }^{18}$ psychological support, ${ }^{19,20}$ and lymphokinetic medications. ${ }^{21}$

In classifying the forms of treatment of lymphedema, lymphokinetic exercises, lymph drainage, and contention mechanisms constitute the basis of the association of techniques. The exercises are defined as programmed and structured muscular activities to improve physical condition and health, but without any objective of competing. ${ }^{22}$ Thus, lymphokinetic exercises are those that, through muscular activities, favor venolymphatic circulation, ${ }^{23}$ however their biomechanic principles, intensity, and duration should be further investigated. ${ }^{24}$

Studies show that low-intensity exercises can be performed by patients with arm lymphedema without risk of worsening the edema. Exercises without the sleeve may be of benefit provided the compression sleeve is worn regularly. ${ }^{25}$ In breast cancer survivors at risk for lymphedema, a program of slowly progressive weight lifting compared with no exercise did not result in increased incidence of lymphedema and reduced symptoms, and increased strength. ${ }^{26,27}$

The aim of the current study was to evaluate the reduction in the volume of the upper limbs with lymphedema after exercises using the apparatus-assisted program associated with contention mechanism.

\section{Patients and method}

Twenty-eight female patients were selected and referred to the Godoy Clinic to evaluate and treat lymphedema. All patients underwent radiotherapy, chemotherapy, and surgery with axiliary lymph node resection. The ages ranged from 42 to 72 years with a mean age of 57 years. Inclusion criteria were a history of breast cancer treatment followed by edema of the arm with a difference between the affected and contralateral limbs of more than $200 \mathrm{~mL}$. Women with active infections, skin lesions, or other active diseases were not included in the study. All participants were informed about the nature of the study and signed written consent forms. Four types of exercises using apparatuses (pedal, pulleys, horizontal bar, and elevation bar; Figure 1) were selected. The patients received guidance related to how the exercise should be performed: time (15 minutes using each apparatus), low intensity (less than 10 movements per minute), posture (seated when exercising), and the use of Godoy and Godoy contention (a sleeve made from a cotton-polyester material). Water displacement volumetry was performed before and after 60 minutes of exercising,

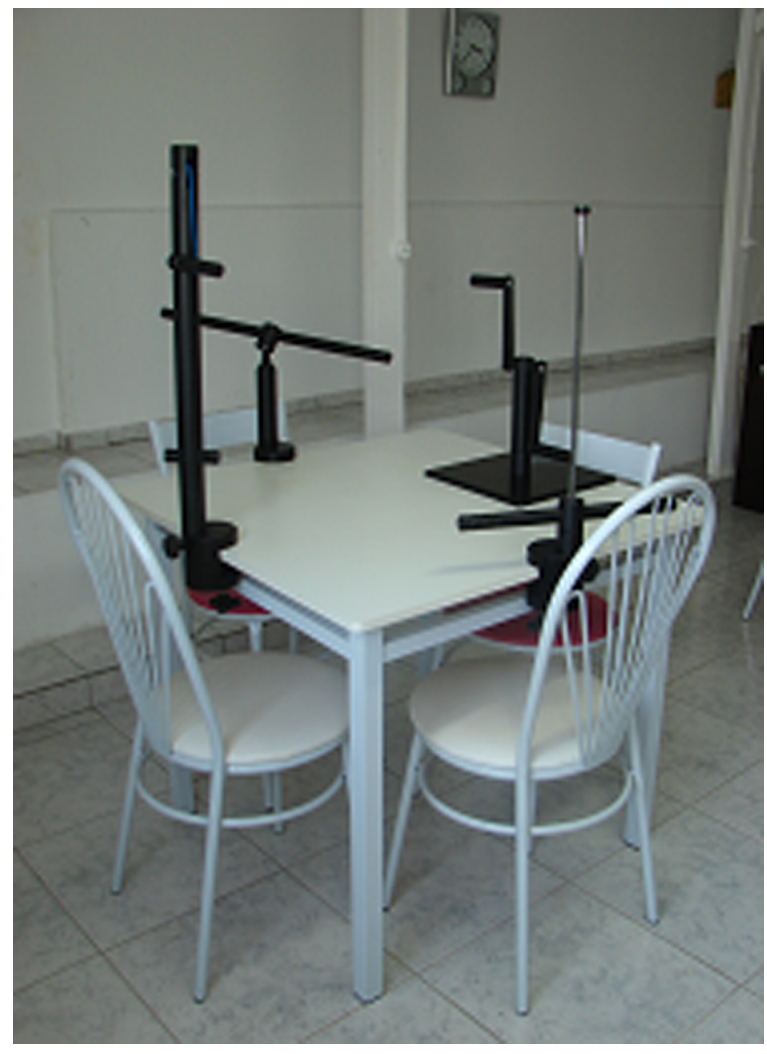

Figure I Table with four exercise apparatuses for the arms.

with the displaced water measured on digital weighing scales. The paired Student's $t$-test was utilized for statistical analysis with an alpha error of $5 \%$ considered acceptable $(P$ value $<0.05)$

\section{Results}

There was a significant difference between the volumetric measurements before and after exercising using the four selected apparatuses over the time and at an intensity determined by this study, the two-tailed $P$ value is 0.0032 , with a mean loss of $57.32 \mathrm{~g}$ (Tables 1 and 2).

\section{Acknowledgments}

This study was financially supported by CAPES.

\section{Discussion}

The present study demonstrated that contention using a sleeve made of a cotton-polyester material associated with exercise reduces the size of the limb when performed using the established parameters. There are no international publications evaluating apparatuses that assist exercise when associated with a contention mechanism in the treatment of lymphedema. Moreover, there are few studies establishing 
Table I Volume of the lymphedematous limb before and after performing exercises using the apparatuses and Godoy \& Godoy contention (cotton-polyester sleeve)

\begin{tabular}{lll}
\hline Patients $\mathbf{( n )}$ & Before volume $\mathbf{( g )}$ & Final volume $\mathbf{( g )}$ \\
\hline $\mathrm{I}$ & $\mathrm{I}, 920$ & 2,050 \\
2 & 2,671 & 2,573 \\
3 & 1,869 & 1,738 \\
4 & 2,973 & 3,037 \\
5 & 1,692 & 1,630 \\
6 & 1,703 & 1,680 \\
7 & 1,910 & 1,908 \\
8 & 2,069 & 1,872 \\
9 & 1,492 & 1,467 \\
10 & 2,343 & 2,420 \\
11 & 2,457 & 2,587 \\
12 & 2,218 & 2,168 \\
13 & 1,792 & 1,583 \\
14 & 1,663 & 1,582 \\
15 & 1,892 & 1,895 \\
16 & 1,443 & 1,336 \\
17 & 1,483 & 1,462 \\
18 & 2,038 & 1,961 \\
19 & 1,363 & 1,260 \\
20 & 1,826 & 1,785 \\
21 & 2,465 & 2,326 \\
22 & 2,213 & 2,181 \\
23 & 1,325 & 1,315 \\
24 & 2,235 & 2,034 \\
25 & 1,678 & 1,543 \\
26 & 1,341 & 1,264 \\
27 & 1,796 & 1,823 \\
28 & 1,654 & 1,439 \\
\hline & &
\end{tabular}

criteria for exercising in the treatment of lymphedema, chiefly in respect to the lower limbs. Even so, exercising constitutes one of the cornerstones in the treatment of lymphedema as recommended in the literature.

The study developed apparatuses from studies of the working pressure exerted by the main muscle groups, associated to a contention mechanism. An attempt was made to develop simple low-cost products which fill the established objectives; to create working pressures with low energy expenditure. The time of each exercise was evaluated in

Table 2 Mean and standard deviation of volume before and after 60 minutes with apparatus exercise

\begin{tabular}{lllll}
\hline & $\begin{array}{l}\text { Initial } \\
(\text { vol })\end{array}$ & $\begin{array}{l}\text { After } \\
\mathbf{6 0} \text { minutes }\end{array}$ & Difference & $\mathbf{P}<\mathbf{0 . 0 0 3}$ \\
\hline $\mathrm{N}$ & 28 & 28 & & \\
Mean & $1,911.6$ & $1,854.3$ & 57.321 & \\
$\begin{array}{l}\text { Standard } \\
\text { deviation }\end{array}$ & 416.55 & 445.92 & 93.732 & \\
$\begin{array}{l}\text { Standard } \\
\text { error }\end{array}$ & 78.720 & $84.27 \mathrm{I}$ & 17.714 \\
\begin{tabular}{l} 
Median \\
\hline
\end{tabular} & $1,847.5$ & $1,804.0$ & 56.000 \\
\hline
\end{tabular}

a pilot study on the tolerance of patients and from this information an evaluation method was established. Some aspects are of fundamental importance when performing exercises such as the velocity and thus patients should be supervised. Higher velocities may increase the volume, instead of reducing it. These findings were obtained with experience acquired in the treatment and from continuous assessment of patients, that is, after each type of activity, water displacement volumetry was performed. It is important to remember that patients try to increase the velocity of the exercises over the treatment period in an attempt to accelerate the result.

Exercises are an important form of treatment when associated with a contention mechanism, however patients must be supervised and frequently assessed, because the edema may increase if the exercises are incorrectly performed. In respect to a contention mechanism during active exercising, it seems to be fundamental, but even so, it can act as a tourniquet and continuous care is required. Another aspect identified in the evaluation of the different forms of exercise for these patients, either when using apparatuses or not, is the necessity of personal adaptation, with professionals suggesting volumetric evaluations for each patient and each programmed activity to identify which activities are best adapted to individuals. This adaptation involves performing exercises in the clinic to their adaptation in the patient's home.

\section{Conclusion}

Association of a Godoy \& Godoy contention during apparatus-assisted exercise reduced the edema in patients with lymphedema of the upper limbs.

\section{Disclosure}

The authors report no conflicts of interest in this work.

\section{References}

1. Godoy JMP, Godoy MFG, Braile DM, Testoni B, Sanches RG. Dynamic evaluation of working pressures with gorgurão sleeves used in the treatment of lymphedema of the arm. J Phlebol Lymphol. 2008;1(1):5-7.

2. Rietman JS, Dijkstra PU, Debreczeni R, Geertzen JH, Robison DP, De Vries J. Impairments, disabilities, and health related quality of life after treatment for breast cancer: a follow-up study 2.7 years after surgery. Disabil Rehabil. 2004;26(2):78-84.

3. Ciucci JL, Karapp JC, Soracco JE, et al. Changes in clinical management and the evolution of an interdisciplinary therapeutic approach: 640 lymphedema patients over 20 years. J Vasc Bras. 2004;3(1):72-76.

4. Foldi M, Foldi E, Kubik S. Lymphostatic disease. In: Textbook of Lymphology. For Physicians and Lymphedema Therapists. Munchen, Germany: Urban \& Fischer; 2003:280.

5. Bordin NA, Godoy MFG, Godoy JMP. Mechanical lymphatic drainage in the treatment of arm lymphedema. Indian J Cancer. 2009;46(4):337-339. 
6. Godoy JMP, Godoy MFG, Braile DM. Lymph drainage in patients with joint mobility due to chronic ulcerated lesions. Phlebology. 2008;23(1): 32-34.

7. Godoy JMP, Godoy MFG. Manual lymph drainage: a new concept. J Vasc Br. 2004;3(1):77-80.

8. Godoy JMP, Braile DM, Godoy MFG. A thirty-month follow-up of the use of a new technique for lymph drainage in six patients. Eur J Vasc Endovasc. 2002;3:91-93.

9. Godoy JMF, Godoy MFG, Batigalia F. Preliminary evaluation of a new, more simplified physiotherapy technique for lymphatic drainage. Lymphology. 2002;35(2):91-93.

10. Wittlinger H, Wittlinger G. Textbook of Dr. Vodder's Manual Lymphatic Drainage. Brussels, Belgium: HAUG; 1995.

11. Godoy MFG, Oliani AH, Godoy JMP. Active exercises utilizing a facilitating device in the treatment of lymphedema resulting from breast cancer therapy. Ger Med Sci. 2010;8:1-4.

12. Mckenzie DC, Kalda A. Effect of upper extremity exercise on secondary lymphedema in breast cancer patients: a pilot study. J Clin Oncol. 2003; 21(3):463-466.

13. Godoy JMP, Godoy MFG. Assessment of inelastic sleeves in patients with upper limb lymphoedema. Indian $J$ Physiother Occup Ther. 2007;1(4):3-5.

14. Artíbale MES, Godoy JMP, Godoy MFG, Braile DM. A new option for compression in the treatment of lymphedema in children. JVasc Br. 2005;4(3):311-313.

15. O’Donnell T. Principles of medical and physical treatment. In: Browse SN, Burnand KG, Mortimer OS, editors. Diseases of the Lymphatics. London, UK: Arnold; 2003:168.

16. Godoy JMP, Silva HS. Prevalence of cellulitis and erysipelas in postmastectomy patients after breast cancer. Arch Med Sci. 2007;3(3): 249-251.

17. Godoy JMP, Braile DM, Godoy MFG, Longo O Jr. Quality of life and peripheral lymphedema. Lymphology. 2002;35(2):72-77.
18. Shaw C, Mortimer P, Judd PA. A randomized controlled trial of weight reduction as a treatment for breast cancer-related lymphedema. Cancer. 2007;110(8):1868-1874.

19. Strauss-Blasche G, Gnad E, Ekmekcioglu C, Hladschik B, Marktl W. Combined inpatient rehabilitation and spa therapy for breast cancer patients: effects on quality of life and CA 15-3. Cancer Nurs. 2005;28(5): 390-398.

20. Cohen SR, Payne DK, Tunkel RS. Lymphedema: strategies for management. Cancer. 2001;92(4 Suppl):980-987.

21. Badger C, Seers K, Preston N, Mortimer P. Antibiotics/anti-inflammatories for reducing acute inflammatory episodes in lymphoedema of the limbs. Cochrane Database Syst Rev. 2004;2:CD003143.

22. European Food Information Council (EUFIC). L'activite physique. June, 2006. Available from: http://www.eufic.org/article/fr/page/BARCHIVE/ expid/basics-activite-physique/. Accessed January 23, 2011.

23. O'Donnell T. Principles of medical and physical treatment. In: Browse SN, Burnand KG, Mortimer OS, editors. Disease of the Lymphatics. London, UK: Arnold; 2003:167.

24. Ken-Dror G, Lerman Y, Segev S, Dankner R. Measurement and assessment of habitual physical activity in epidemiological studies. Harefuah. 2005;144(3):229-230. Hebrew.

25. Johansson K, Tibe K, Weibull A, Newton RC. Low intensity resistance exercise for breast cancer patients with arm lymphedema with or without compression sleeve. Lymphology. 2005;38(4):167-180.

26. Schmitz KH, Ahmed RL, Troxel A, et al. Weight lifting in women with breast-cancer-related lymphedema. N Engl J Med. 2009;361(7): 664-673.

27. Schmitz KH, Ahmed RL, Troxel AB, et al. Weight lifting for women at risk for breast cancer-related lymphedema: a randomized trial. JAMA. 2010;304(24):2699-2705.
International Journal of General Medicine

\section{Publish your work in this journal}

The International Journal of General Medicine is an international, peer-reviewed open-access journal that focuses on general and internal medicine, pathogenesis, epidemiology, diagnosis, monitoring and treatment protocols. The journal is characterized by the rapid reporting of reviews, original research and clinical studies across all disease areas.

\section{Dovepress}

A key focus is the elucidation of disease processes and management protocols resulting in improved outcomes for the patient. The manuscript management system is completely online and includes a very quick and fair peer-review system. Visit http://www.dovepress.com/ testimonials.php to read real quotes from published authors. 